\title{
The Study of Moderating Role of Social Capital in the Relationship between Development of Urban Tourism and Sustainable Urban Development (Case Study: Zahedan)
}

\author{
Masoumeh Hafiz Rezazadeh, Fatemeh Hashem Zehi, Raziye Eslami Rad \\ Geography and Urban Planning, Faculty of Humanities, Islamic Azad University, Zahedan Branch, Zahedan, Iran \\ Email: m_hafezrezazadeh2014@yahoo.com
}

How to cite this paper: Rezazadeh, M. H. Zehi, F. H., \& Rad, R. E. (2016). The Study of Moderating Role of Social Capital in the Relationship between Development of Urban Tourism and Sustainable Urban Development (Case Study: Zahedan). Current Urban Studies, 4, 461-475.

http://dx.doi.org/10.4236/cus.2016.44030

Received: April 6, 2016

Accepted: November 28, 2016

Published: December 1, 2016

Copyright $\odot 2016$ by authors and Scientific Research Publishing Inc. This work is licensed under the Creative Commons Attribution International License (CC BY 4.0).

http://creativecommons.org/licenses/by/4.0/

\begin{abstract}
The aim of this paper is to study moderating role of social capital in development of tourism and sustainable urban development in the city of Zahedan. We prepared a questionnaire with 30 questions; and based on Cochrane's sample, we distributed 114 questionnaires among managers of Tourist Organization and hotel managers with a random sampling. Based on these results, Zahedan city does not have a good situation in sustainable development. For testing the hypotheses, single-sample T-test, Pearson's correlation and hierarchal linear regression were applied. Also the result of testing hypotheses indicates that there is a positive relationship between tourism development and sustainable urban development. In addition, the third hypothesis test showed that social capital had a moderating role on the relationship between development of tourism and sustainable urban development so much that based on hierarchical linear regression test, $25 \%$ of the variance in sustainable urban development is explained by the moderating role of social capital.
\end{abstract}

\section{Keywords}

Moderating Role, Social Capital, Development of Urban Tourism, Sustainable Urban Development

\section{Introduction}

Today, tourism has developed and progressed widely and by the use of tourism, many countries have been able to improve their situations considerably and solve many 
problems such as unemployment, lowness of per capita income and foreign exchange income (Szpilko, 2015). Economists regard tourism as the third rising dynamic economic phenomenon after oil and car industries. Development of tourism as a set of economic activities, has a significant impact on supporting foundations of community especially economically (Lankford \& Howard, 1994: p. 122). This is so much that development of tourism, especially in developing countries, has been accepted widely and has been placed in the governments' platforms (Ko \& Stewart, 2002: p. 523). Of course, mismanagement in the field of tourism can have very bad consequences on the environment (Malik and Bhat, 2015). These negative effects have been approved on both environment and urban development (Atik, Sayan, \& Karagüzel, 2009; Barros, Gonnet, \& Pickering, 2013; Cohen, 1978; Croall, 1995; Farooquee, Budal, \& Maikhuri, 2008; Malik, Bhat \& Kuchay, 2011; Rashid \& Romshoo, 2012; Zabortseva \& Yevstropieva, 2009). Sustainable development is one of the important subjects in tourism (Bodosca and Diaconescu, 2015). The objective of sustainable urban development is to improve quality of life for cities with high population or for the developing cities (Deakin and Reid, 2014). A developed society passes all disadvantages, such as economic, political and social difficulties until it achieves the desired and defined conditions. However, sustainable development is a process in which the welfare of society continues for a long time without disrupting the transition process (Ostad Hoseyn and Kohnabi, 2003). So, development of urban tourism should be considered in line with sustainable urban development as far as it isn't destructive and provides the possibility to maintain soil, water, genetics, plants, and animal resources for the posterity. In fact, sustainable urban development is one that can continue in an environment for an unlimited time and does not cause any human or physical damages to the social, cultural, environmental, etc. issues and is so much active that it does not bring damage to development of other social activities and processes (Butler, 2000: p. 29).

Today, traditionally it is indicated that there are three types of capital (natural, physical and human) which altogether are a basis for economic development and performance (Zhang \& Hung, 2006). So, the development of any society depends on increasing the level of social capital in its own active institutions and organizations (Putnam, 1995: pp. 65-78). Social capital generally includes the institutions, relations, attitudes, values and norms that govern people's behaviors and attitudes. In other words, social capital is those networks and norms that enable people to act collectively (Woolcock \& Narayan, 2000). In this view, social capital is an indivisible part of a whole nation's wealth, and within the framework of theory of sustainable development, creating, maintaining and enriching it to the posterity are goals that sustainable development is required to follow (Salari Sardari et al., 2014).

Based on these statements, the aim of this paper is to study relationship between development of urban tourism and sustainable urban development in Zahedan as one of the developing cities and one of the most important centers of tourism in the southeast of Iran. Furthermore, one of the goals of the researchers in this paper is to study moderating role of social capital on sustainable urban development. 


\section{Theoretical Foundations of Research}

\subsection{Social Capital}

The concept of social capital first was used by Alfred Marshal (1980) (Elmi, Sharei Pour and Hosseini, 2006: p. 242), although he used it in a different meaning than what is now being used in the social sciences. According to Coleman, social capital is people's ability to communicate effectively with each other (Coleman, 1988). In the 1980s, Bourdieu introduced social capital as a set of actual and potential resources that emerge as a result of institutionalized networks (Bourdieu, 1983). Fukuyama also introduced social capital as an individual's ability to perform group activities to reach common goals (Fukuyama, 1995: p. 10). Putnam introduced social capital as the appearance of social institutions such as confidence, norms (or interaction) and the networks that can lead to improve the efficiency of society in purist of common interests by facilitating correlation and cooperation (Suharto, 2007).

Accordingly, social capital can be introduced as a set of different but related concepts to each other, like social networks, mutual communications and perception, public confidence, and commitment. In fact, social capital is created when people have reciprocal relationship at work, family, community or neighborhood (Basterlaer and Groodna, 2003).

Social capital has a very important role in coherenc among human resources; and in the absence of it, other capitals lose effectiveness; without it, achieving ways of development is impossible, and cannot be effective (Alvani, 1999: pp. 8-10). Social capital can provide an appropriate foundation for human resources to benefit from, so that human resources can fulfill their commitments by more participation, reciprocal trust and increasing their professional knowledge (Mirsepasi, 2004). On the other hand, benefitting from other capitals is possible in the light of this capital. Social capital and other capitals can be effective variables in efficiency of social activities and to get significant role in the process of development (Fukuyama, 1995: p. 80).

\section{Components of Social Capital}

Researchers believe that social capital has different components the most important of which are:

Social Confidence: confidence is one of the most important constituent elements of social capital and is a key element in any society and seems to be necessary to solve social problems. Confidence is the feeling of social relationships and has a direct relationship with the amount of social relations. So, the more social confidence exists among people, groups and social organizations of the society, the more intensive, varied and stable the social relations will become (Tavakoli and Tajbakhsh, 2008).

Social Participation: participation means using personal resources to share in a collective action. Social participation has its roots in the communal structure and relationships in the local and national levels, and is eventually based on a process, a process which establishes reliability and correlation among people (Rastgar Khalid et al., 2013). In fact, one of the planning tools in the modern world is creating active and effective 
participation of citizens in different phases of development projects. Therefore, active participation is one of the important aspects of social capital (Tabrizi, 1990: p. 54).

Social Norms: These norms can be regarded as a premise or as unwritten social rules, for example, norms of helping and being good citizens (Dakhli and de Clercq, 2004). Social norms and social confidence are very close and related to each other. Civil norms which conduct people's behaviors can be seen as a reliability that improves confidence among others (Kaasa, 2009). On the other hand, one of the important norms is social interaction. People act in favor of others and expect them to help them when they need. Therefore, if there is enough confidence in the community, it will be highly expected that others show interaction and people tend to follow civil norms in their behaviors. .

Social Coherence and Cohesion: Social coherence and cohesion means that the group should maintain its unity, and should have compliance and conformity with its unifying elements. This is a responsibility among some people and some groups that have awareness and capability of presentation. It includes a moral meaning which guarantees existence of the idea of duty or a reciprocal commitment; and also a positive concept rises from it which shows reciprocal dependence of functions, components and/or entities in a structured totality. From a sociological perspective, correlation is a phenomenon according to which in a group or a society, members are dependent and reciprocally need one another. This does not require repulsing awareness and moral rejection based on reciprocation and responsibility; but it is an invitation to gain these values and feel mutual commitment (Birou, 2001).

Moral Values: one of the elements that bring social capital to the society or even itself is considered as a social capital is moral values. In the light of social values, social capital, as a facilitator of social relationships, finds the chance to outbreak, appear and get strength. On this basis, human values, norms as well as ideological and moral patterns spread in an expansive level in the society. Therefore, moral values could tangibly be factors for reinforcement of social capital (Mohseni Tabrizi and Agha Mohseni, 2010).

\subsection{Sustainable Urban Development}

In the 1980s, the concept of sustainable development was introduced with this perception that unlimited continuous economic growth would lead to undesirable environmental and social consequences. It challenged economic development and growth patterns that had appeared by then (Barbour, 1993). In 1987, Brant Land Commission related to the United Nations, used the term "sustainable development" for the first time in official communities. This commission introduced sustainable development as to fulfill human needs without putting at risk fulfillment of needs of the posterity (Krause, 1996: pp. 12-13).

Sustainable urban development can be defined as a development that tries to continuously fulfill human needs and provide their satisfaction along with enhancing quality of their lives (Allen, 1998: 15). 
Sustainable development is simultaneous operation of three dimensions of economy, society and environment to achieve the collective goals of welfare, livelihood, uprooting poverty, public enjoyment of desired life and increasing the scope of benefitting from natural resources (sustainable development) (Salari Sardari et al., 2014). In fact, sustainable development can be considered as having three dimensions i.e. economic, social and ecologic dimensions (Spitzer, 1997: p. 60). These dimensions include a clear structure and a hierarchical system; in addition to that, every one of these dimensions has its own specific weight in sustainable development. Determining the weight of every one of them depends on the features of the studied subject (Birkman, 2000: pp. 167-169). Therefore, sustainable development does not only depend on environmental policies, and without solving social and economic problems, sustainable development cannot be achieved. It also requires a comprehensive perspective in environmental, social and economic policies of development and integration in these dimensions (Kanatsching \& Weber, 1998: p. 22).

Objectives of sustainable urban development are determined in order to extract the guidelines applied in the following processes of development (Behrendt, 2000: p. 18). Objectives of sustainable urban development are in accordance with dimensions of sustainable development, and these objectives are compiled according to these dimensions.

Environmental Objectives: According to the attitude of sustainable development, these objectives include subjects such as reduction of energy consumption, and using spaces as other resources. In addition, it is necessary to improve performance to increase productivity and resources. The resources should be used economically so that they can be reproduced and no negative consequences be created for using other resources (IRPUD, 1993). Additionally, the surrounding and influenced areas should not be put under pressure. . One of the solutions to prevent these is decentralization which is created by circulation of the economy in the area (University of Dortmund, 2001: p. 26).

Economic Objectives: In relation to economic dimension, the resources within the area should be identified and should become a developed network to create regional development. The related foreign companies should let the economy circulate in the area and reduce negative consequences. Added values of economic activities in the area should be stabilized and economic structures should be moderated to solve economic crisis (University of Dortmund, 2001: p. 27).

Social Objectives: Identification of the landscape and cultural andhistorical features should be established to create a regional identity. Supporting social resources should be done by creating the right conditions (Becker, 1995: p. 22).

\subsection{Development of Urban Tourism}

Development of tourism is considered as one of the good ways to develop the country. For example, development of tourism is a way through which the government can involve people in transport industry. Malaysia is one of the countries that provided many job opportunities for its own people (Fitri Amir et al., 2015).

On the other hand, tourism development can be a way to ensure income of the society (Pusiran \& Xiao, 2013). In many countries of the world, tourism acts as one of the 
key parts to develop and promote economic conditions (Zahedi, 2006: p. 40). As the studies show, development of tourism has a direct impact on improving quality of people's lives in that area (Nunkoo \& Ramkissoon, 2011).

The concept urban tourism has entered the list of studies in 1980 (Dinari, 2005: 3). Because of having a lot of historical and cultural attractions, urban areas are considered as important tourist destinations (Timothy \& Wall, 1995: 6). The cities usually have a large variety of museums, monuments, and historical sites to attract tourists (Hall \& Page, 2001).

On the other hand, due to the low cost and short time of transportation in cities to get to the tourist areas, tourists show more tendencies to visit cities (Cooper et al., 1998: p. 42). Urban tourism is traveling to cities with different incentives based on the different attractions and facilitative services available in the cities which attract the individuals (Law, 1996: p. 25). Of course, different objectives could be regarded for urban tourism some of which are visiting friends and relatives, taking part in exhibitions and conferences, visiting cultural and entertainment locations, fulfilling medical-healthcare requirements, doing business, etc. (Hall \& Page, 1999: p. 167).

In addition to the mentioned cases, tourism has several positive and negative effects on urban development. Some of the positive effects are listed in Table 1.

\section{Research Methodology}

Since the study can be used by municipality managers and tourism officials, it is an applied study, and considering the identity and objectives, it is descriptive-survey type.. Statistical society of research is managers and personnel of Zahedan Tourist Organization as well as managers of hotels and restaurants in this city. The population size is

Table 1. Positive effects of development of urban tourism (Hataminejad \& Sharifi, 2015).

\begin{tabular}{|c|c|}
\hline Dimension & Type of Effect \\
\hline Economic & $\begin{array}{l}\text { Creating new markets for the sale of traditional products } \\
\text { equality of employment opportunities in the society (Mccool, 1995) } \\
\text { increasing labor supply (Harseel, 1994) } \\
\text { increasing the quality of life (Harseel, 1994) } \\
\text { creating jobs and increasing public revenues } \\
\text { expansion of hidden export (Harseel, 1994) }\end{array}$ \\
\hline Social_cultural & $\begin{array}{c}\text { Attraction of population } \\
\text { general freshness and happiness because of wide presence of tourists } \\
\text { promoting residents' quality of life } \\
\text { strengthening the pride of host communites and spirit of correlation } \\
\text { Improving awareness of the inhabitants } \\
\text { revival of local arts and traditions }\end{array}$ \\
\hline Physical-environmental & $\begin{array}{l}\text { Development of new facilities and infrastructure (Shahabian, 2010) } \\
\text { Protection of ancient heritage } \\
\text { Modernization and repairing of buildings and historical sites (Lea, 1988) } \\
\text { Changing use of old buildings on the basis of new needs (Lea, 1988). } \\
\text { Attention to the cleanliness of tourist sites. (Shahabian, 2010) } \\
\text { Increasing residents' natural and cultural awareness }\end{array}$ \\
\hline
\end{tabular}


162. Cochrane formula was used for determining the sample size which with the $95 \%$ confidence level, the sample size reached 114 individuals. . In order to collect the data a questionnaire of 35 questions was designed; and to evaluate its content justifiability, the opinions of experts and teachers were taken, and to assess the perpetuity, Cronbach's alpha coefficient was applied. The value of this index was gained $0.831 \%$ which considering the fact that it is more than 0.7 , it indicates that it has the required perpetuity. The questionnaire includes 7 questions related to development of urban tourism, 16 questions on social capital, and 12 questions are to study sustainable urban development. The questionnaires were distributed among the statistical population of study randomly among 114 individuals. Eventually, collected data was tested by software SPSS 20 to test the hypotheses of research.

\section{Research Hypotheses}

This study includes three hypotheses which were evaluated and tested by the use of single-sample statistics of T-test, Pearson's correlation and multiple linear regression tests. These hypotheses include:

First Hypothesis: Zahedan is in a desirable level in terms of sustainable development.

Second Hypothesis: Tourism development has a positive and meaningful impact on sustainable urban development.

Third Hypothesis: Social capital has a moderating role in the relationship between development of urban tourism and sustainable urban development.

\section{Research Findings}

In order to analyze findings of the research we applied descriptive and inferential statistics. The results are as follows:

\subsection{Descriptive Findings}

Studying the individual features of survey respondents indicated that out of the total number of 114 respondents, 53 (46.6\%) are females and 71 (53.4\%) are males. The percentage of respondents in terms of age shows that $28 \%$ of respondents are in the range of 20 to 25 years, $41.7 \%$ are in the range of 25 to $30,18.2 \%$ in the range of 30 to 35 , and $11.5 \%$ are in the range of more than $35 \%$. More than $52 \%$ have master's degree or higher, $31 \%$ have bachelor's degree and the rest have lower education. Also $82 \%$ of respondents were married and $18 \%$ were single. Employment status of the respondents showed that $49 \%$ of them were employees of Tourist Organization, 34\% were hotel managers and $17 \%$ Zahedan restaurant managers.

\subsection{The Analytical Findings and Testing Hypotheses}

As it was mentioned, this study includes the following three hypotheses that are tested using inferential statistics. 


\subsubsection{The First Hypothesis Test}

H0: Zahedan isn't in a good level in terms of sustainable urban development.

H1: Zahedan is in a good level in terms of sustainable urban development.

In this study, in order to examine sustainable urban development, 12 questions were presented. Every four questions are about one of the economic, social, and environmental dimensions of sustainable development. By the use of single-sample T-test, Table 2 will evaluate the status of each one of the aspects of sustainable urban development in Zahedan. It will also examine the first hypothesis.

As seen in Table 2, for the three dimensions of sustainable urban development in Zahedan city, the level of significance is obtained less than 0.05 , but for the social and environmental dimensions, the $t$ value is negative and for economic dimensions, it has been measured as positive. Therefore, from the prospect of statistical society of this survey, social and environmental aspects of sustainable urban development in Zahedan city are not desirable but the economic dimension of sustainable urban development is desirable. To evaluate the first hypothesis, the T-test results in Table 2 in the row sustainable urban development were applied. As it can be seen, this test's level of significance is obtained less than 0.05 , and also the value $t$ is measured as negative $(-4.731)$. Therefore, from the prospective of statistical society of this study, the assumption H0 related to the first hypothesis is rejected and $\mathrm{H} 1$ is approved. As a result, according to the perspectives of managers of the Tourist Organization as well as hotel and restaurant managers in the city of Zahedan, this city is not in a good level in terms of sustainable urban development. In other words, the city is still in the early stages of development and it is yet to reach sustainable development.

\subsubsection{The Second Hypothesis Test}

H0: Development of urban tourism doesn't have a positive and meaningful impact on the sustainable urban development.

H1: Development of urban tourism has a positive and meaningful impact on the sustainable urban development.

Before checking the second hypothesis of the study, situation of Zahedan tourism development from the prospective of statistical society is analyzed by the use of, single-sample T-test using statistical population.

The test results are in Table 3.

As shown in Table 3, the average value of responses is obtained as 2.51 which is less

Table 2. Status of sustainable urban development in Zahedan city and first hypothesis test (measurements of the researcher, 2015).

\begin{tabular}{ccccc}
\hline & $\mathrm{t}$ & $\mathrm{df}$ & Significant level & Average \\
sustainable urban development & -5.73 & 113 & 0.000 & $3 / 68$ \\
environmental dimension & -12.798 & 113 & 0.000 & $3 / 10$ \\
economic dimension & 3.528 & 113 & 0.000 & $3 / 21$ \\
Social dimension & -4.072 & 113 & 0.000 & $2 / 74$ \\
\hline
\end{tabular}


Table 3. The development of tourism in Zahedan.

\begin{tabular}{ccccc}
\hline \multirow{3}{*}{ T_value $=3$} & & \\
2.51 & level of significance & df & $t$ & \\
& 000 & 113 & $-7 / 138$ & Development of urban tourism \\
\hline
\end{tabular}

than the average value (3). Also the level of significance in the single-sample T-test is less than 0.05 and the value of $t$ is measured as negative. Therefore, according to the prospective of the statistical society of the study, development of urban tourism in Zahedan is not in a desirable level. However, considering the fact that the average value of $51 / 2$ is obtained, the situation is week but improving.

As shown in Table 4, the significance level of Pearson's correlation is achieved less than $05 / 0$.Therefore, the second hypothesis is approved at the level of $95 \%$ confidence and therefore development of urban tourism is effective on sustainable urban development. Since the R value or Pearson's correlation coefficient is positive and equal to 0.619 , the relationship is positive and almost strong. In other words, according to perspectives of managers of Zahedan Tourist Organization and managers of hotels and restaurants in Zahedan, if urban tourism develops in this city, sustainable urban development will also improve. In order to evaluate the effects of development of urban tourism on the dimensions of sustainable urban development, Pearson's correlation test was applied. Results of this test are indicated in Table 5.

As shown in Table 5, the levels of significance related to all three dimensions of sustainable urban development is achieved less than 0.05. Therefore, according to the perspectives of the statistical society, development of urban tourism has significant effect on all three dimensions of sustainable urban tourism. According to the values of correlation coefficient, it is identified that development of urban tourism has the greatest impact $(R=0.731)$ on economic dimensions of sustainable urban development, and has also minimal impact $(\mathrm{R}=0.359)$ on environmental dimensions of sustainable urban development.

\subsubsection{The Third Hypothesis Test}

H0: Social capital hasn't a moderating role in the relationship between development of urban tourism and sustainable urban development.

H1: Social capital has a moderating role in the relationship between development of urban tourism and sustainable urban development.

To investigate the moderating role of social capital in the relationship between development of urban tourism and sustainable urban development from the statistical perspective of this study, we used multiple linear hierarchical regression test (Baron and Kenny's method, (1986)).

The results of this test are stated in Table 6 .

As you can see in Table 6, in the first model, before studying the moderating effect of the variable of social capital, coefficient of determination is equal to 0.185 . After entering the moderating effect of the variable social capital (development of urban tourism $\times$ 
Table 4. The second hypothesis test (measurements of the researcher, 2015).

\begin{tabular}{cccccc}
\hline & independent variable & dependent variable & $\mathrm{R}$ & approx & Significant level \\
$\begin{array}{c}\text { Second } \\
\text { hypothesis }\end{array}$ & $\begin{array}{c}\text { development } \\
\text { of urban tourism }\end{array}$ & $\begin{array}{c}\text { sustainable } \\
\text { urban development }\end{array}$ & 0.619 & 8.803 & 0.000 \\
\hline
\end{tabular}

Table 5. The impact of development of urban tourism on dimensions of sustainable urban development.

\begin{tabular}{ccccc}
\hline Independent variable & $\begin{array}{c}\text { dependent variable (dimension of } \\
\text { sustainable urban development) }\end{array}$ & $\mathrm{R}$ & Approx T & Significant level \\
Environmental dimension & $0 / 359$ & $3 / 114$ & $0 / 000$ \\
$\begin{array}{c}\text { Development } \\
\text { of urban tourism }\end{array}$ & economic dimension & $0 / 731$ & $12 / 395$ & $0 / 000$ \\
& social dimension & $0 / 520$ & $5 / 449$ & $0 / 000$ \\
\hline
\end{tabular}

Table 6. The moderating role of social capital in the relationship between development of urban tourism and sustainable urban development from.

\begin{tabular}{|c|c|c|c|c|c|c|}
\hline Model & Independent variable ${ }^{*}$ & $\mathrm{R}$ & $\mathrm{R}^{2}$ & $\wedge \mathrm{R}^{2}$ & $\wedge f$ & $\mathrm{P}$ \\
\hline 1 & $\begin{array}{l}\text {-Development of urban tourism } \\
\text {-Social capital }\end{array}$ & $0 / 431$ & $0 / 185$ & $0 / 174$ & $4 / 312$ & $0 / 000$ \\
\hline \multirow[t]{2}{*}{2} & $\begin{array}{l}\text {-Development of urban tourism } \\
\text {-Social capital } \\
\text { Development of urban tourism }\end{array}$ & $0 / 652$ & $0 / 425$ & $0 / 251$ & $08 / 543$ & $0 / 000$ \\
\hline & Social capital & & & & & \\
\hline \multirow[t]{2}{*}{ model } & Variables & B & B & & $\mathrm{P}$ & $\mathrm{T}$ \\
\hline & Development of urban tourism & $0 / 161$ & $0 / 413$ & & $4 / 208$ & $0 / 000$ \\
\hline \multirow{2}{*}{1} & Social capital & $0 / 234$ & $0 / 607$ & & $8 / 121$ & $0 / 000$ \\
\hline & Social capita & $0 / 244$ & $0 / 233$ & & $7 / 632$ & $0 / 000$ \\
\hline \multirow[t]{2}{*}{2} & development of urban tourism & $0 / 237$ & 0246 & & $8 / 440$ & $0 / 000$ \\
\hline & Social capita & $0 / 277$ & $0 / 504$ & & $11 / 290$ & $0 / 000$ \\
\hline
\end{tabular}

*dependent variable: sustainable urban development.

social capital) in the second model, it is observed that the coefficient of determination has increased by 0.251 . This shows that firstly $25.1 \%$ of the variance sustainable urban development is explained by the moderating effect of the variable social capital. Secondly, the more the value of social capital in the society increases, the more its moderating effect will increase. In other words, it reinforces the relationship between development of urban tourism and sustainable urban development. As a result, from the prospective of the statistical society of the study, the third hypothesis is approved too. Therefore, social capital has a moderating role in the relationship between development of urban tourism and sustainable urban development.

\section{Conclusion}

Zahedan is a city that, due to the geographical reasons and security issues after the rev- 
olution especially in the sixties and seventies, has not been known as a favorable city to travel and visit in the eyes of tourists. But over the past decade, despite the persistence of serious obstacles especially the mental barrier of lack of security, we have been witnessing domestic and sometimes foreign travelers tending to visit this city. Although the plentitude of barriers and lack of facilities are to the extent that there are many difficulties for tourists, the rising number of tourists in recent years can itself be a significant issue to begin the development of this city. Distinction between Zahedan and many other cities in Iran in terms of trade, language, religion, and weather is the factor that increases tourists' incentive to travel to this part of the country. However, this city needs more attention by relevant authorities to be able to become one of the major tourist hubs in Iran.

From the perspective of research statistical population, the first hypothesis was rejected and as a result, from the view of tourism managers as well as managers of hotels and restaurants in Zahedan city, this city has undesirable conditions in terms of sustainable urban development. According to the analyses carried out among different aspects of sustainable urban development, only the economic situation is at good level while environmental and social dimensions are in undesirable conditions. So Zahedan's municipal and tourism executives and officials need to pay special attention to these aspects of the city. Increasing security to reduce different crimes and decreasing ethnic conflicts through strengthening the unity among religions as well as strengthening ethnic unity are some considerable points in social dimension of this city. Also, paying more attention to the appearance of the city, building parks and proper entertainment places, improving road infrastructure, paying attention to the beauty and collecting urban sewage and garbage are some of significant highlights of the environmental aspect in this city.

According to the conducted test, the second hypothesis was confirmed from the perspective of statistical population, thus there is significant positive relationship between the development of urban tourism and sustainable urban development. This result corresponds with the results obtained from research done by Noori and Zandi (2013), and Zamfir and Corbos (2015). Therefore, the more the city moves towards urban development, the more it can be improved in the field of sustainable urban development. Based on the results of correlation test between variables of development of urban tourism and dimensions of sustainable urban development, the highest correlation was between the development of urban tourism and the economic dimension. Thus, the more the city is developed in the field of tourism and the more attention the officials pay to this subject, the more the city will improve economically and more job opportunities will be created for people, their income will increase, and per capita income of the country and city will rise . Besides, development of urban tourism has a positive impact on social and environmental dimensions and paying more attention to the tourism can also improve social as well as environmental conditions of the city. However as it is observed from the results, development of urban tourism has a less positive effect on the environmental dimension, which is probably due to the increased urban pollution and the garbage produced by presence of more tourists. 
The third hypothesis of the research was also confirmed by tourism organization managers as well as executives of hotels and restaurants, thus social capital plays a moderating role in the relationship between development of urban tourism and sustainable urban development. In studies conducted by Daryabari et al. (2015) and Moayedi and Kheiruddin (2014), the relationship between social capital and sustainable urban development was confirmed. Also, in researches done by Moscardo et al. (2013) and McBeth et al. (2004), the relationship between development of tourism and social capital was verified too. But none of the studies done has ever addressed mediating role of social capital in the relationship between development of urban tourism and sustainable urban development, and this is one of the most important innovations of this work. According to the hierarchical linear regression analysis, $25.1 \%$ of the variance of sustainable urban development is explained by the moderating effect of social capital. So, the more the social capital in the city is strengthened, the more the relationship between development of urban tourism and sustainable urban development is reinforced. Therefore, municipal and cultural executives are recommended to pay more attention to social capital in addition to strengthening tourism infrastructures of the city and considering sustainable urban development, because reinforcement of social capital can facilitate the process of achieving sustainable urban development through development of urban tourism. The more the participation of citizens in municipal activities is increased, the more they desire to host tourists in a better way and thus the city will be moving towards further development. Also, creating unity and communion between citizens of different ethnicities and religions is another factor that can affect the relationship between development of tourism and sustainable urban development by improving social capital. City managers should try to increase social capital in the society as a moderating factor of the relationship between development of tourism and sustainable urban development through promoting moral values in the city, and improving citizens' trust in municipal authorities and other fellow citizens.

\section{References}

Allen, R. (1998). How to Save World Kogan Paye. London.

Alvani, S. M. (1999). Role of Management in Creating and Development of Social Capital. Tadbir Monthly Magazine, 100.

Atik, M., Sayan, S., \& Karagüzel, O. (2009). Impact of Recreational Trampling on the Natural Vegetation in Termessos National Park, Antalya-Turkey. Journal of Agricultural Science, 15, 249-258.

Barbour, J. (1993). Ethics in an Age of Technology. San Francisco: Harper Collines.

Barros, A., Gonnet, J., \& Pickering, C. (2013). Impacts of Informal Trails on Vegetation and Soils in the Highest Protected Area in the Southern Hemisphere. Journal of Environmental Management, 127, 50-60. http://dx.doi.org/10.1016/j.jenvman.2013.04.030

Becker, C. (1995). Nachhaltige Regionalentwicklung mit Tourismus: Ein Strategienrahmen: 21-31. In Institut für Tourismus der Freien Universität Berlin, Arbeitskreis Freizeit und Fremdenverkehrsgeographie (Pub.): Ansätze für eine nachhaltige Regionalentwicklung mit Tourismus. Berlin: Verlag für Universitäre Kommunikation. 
Behrendt, U. (2000). Nachhaltige Raumentwicklung an der deutsch-polnischen Grenze. Dortmund: Diplomarbeit.

Birkman, J. (2000). Nachhaltige Raumentwicklung imdreidimensionalen Nebel. UVP-Gesellschaft: UVP-Report 3. Hamm: UVP-Verlag.

Birou, A. (2001). Dictionary of Social Sciences. Saroukhany (Translated). Tehran: Keyhan Publications.

Bourdieu, P. (1983). The Forms of Capital. In J. G. Richardson (Ed.), Handbook of Theory and Research for the Sociology of Education (pp. 241-258). New York: Greenwood Press.

Butler, R. W. (2000). Ecotourism-Has It Achieved Maturity or Has the Bubble Burst? New Zealand: Keynote Address pacific rim Tourism Rotorua.

Cohen, E. (1978). Impact of Tourism on the Physical Environment. Annals of Tourism Research, 5, 215-237. http://dx.doi.org/10.1016/0160-7383(78)90221-9

Coleman, J. (1988). Social Capital in the Creation of Human Capital. American Journal of Sociology, 94, 95-120. http://dx.doi.org/10.1086/228943

Cooper, C., Fletcher, J., Gilbert, D., Wanhill, S., \& Shepherd, R. (1998). Tourism: Principles and Practice (2nd ed.). New York: Longm.

Croall, J. (1995). Preserve or Destroy: Tourism and the Environment. London: Calouste Gulbenkian Foundation.

Dakhli, M., \& de Clercq, D. (2004). Human Capital, Social Capital, and Innovation: A MultiCountry Study. Entrepreneurship and Regional Development, 16, 107-128. http://dx.doi.org/10.1080/08985620410001677835

Deakin, M., \& Reid, A. (2014). Sustainable Urban Development: Use of the Environmental Assessment Methods. Sustainable Cities and Society, 10, 39-48. http://dx.doi.org/10.1016/j.scs.2013.04.002

Elmi, Z., Sharei Pour, A., \& Hosseini, M. (2006). Social Capital and Impact of It on Economy. Journal of Research Economy, 71, 239-296.

Farooquee, N. A., Budal, T. K., \& Maikhuri, R. K. (2008). Environmental and Socio-Cultural Impacts of River Rafting and Camping on Ganga in Uttarakhand Himalaya. Current Science, 94, 587-594.

Fitri Amir, A., Ghapar, A. A., Jama, S. A., \& Ahmad, K. N. (2015). Sustainable Tourism Development: A Study on Community Resilience for Rural Tourism in Malaysia. Procedia-Social and Behavioral Sciences, 168, 116-122. http://dx.doi.org/10.1016/j.sbspro.2014.10.217

Fukuyama, F. (1995). Social Capital and the Global Economy. Foreign Affairs, 74, 89-103. http://dx.doi.org/10.2307/20047302

Hall, C. M., \& Page, S. J. (1999). The Geography of Tourism and Recreation. London: Routledge.

Hall, C. M., \& Page, S. J. (2001). Tourism and Recreation. London: Routledge.

Hataminejad, H., \& Sharifi, A. (2015). The Role of Urban Tourism Development in Sustainable Urban Development (Urban Sample: Sanandaj). Urban Tourism, 2, 61-74.

IRPUD (Pub.) (1993). Endogene Regionalentwicklung ein Konzept für die SächsischeSchweiz. Dortmund: IRUPD Verlag.

Kaasa, A. (2009). Effects of Different Dimensions of Social Capital on Innovative Activity: Evidence from Europe at the Regional Level. Technovation, 29, 218-233. http://dx.doi.org/10.1016/j.technovation.2008.01.003

Kanatsching, D., \& Weber, G. (1998). Nachhaltige Raumentwicklung in Österreich. Schriftenreihe des Österreichischen Instituts für Nachhaltige Entwicklung, Band 4, Wien: Österreichisches Institut für Nachhaltige Entwicklung. 
Ko, D. W., \& Stewart, W. P. (2002). A Structural Equation Model of Residents' Attitudes for Tourism Development. Tourism Management, 23, 521-530. http://dx.doi.org/10.1016/S0261-5177(02)00006-7

Krause, M. (1996). Nachhaltigkeit: Dimension eines Begriffs und seine Bedeutung fur die räumliche Planung. Berlin: Freie Universität Berlin, Fachbereich Geowissenschaften, Institut für Geographische Wissenschaft.

Lankford, S. V., \& Howard, D. R. (1994). Developing a Tourism Impact Attitude Scale. Annals of Tourism Research, 21, 121-139.

Law, C. (1996). Urban Tourism: Attracting Visitors to Large Cities. London: Mansell Publishing Limited.

Lea, J. (1988). Tourism and Development in the Third World. Abingdon-on-Thames: Routledge.

Malik, M. I., \& Bhat, M. S. (2015). Sustainability of Tourism Development in Kashmir-Is Paradise Lost? Tourism Management Perspectives, 16, 11-21. http://dx.doi.org/10.1016/j.tmp.2015.05.006

Malik, M. I., Bhat, M. S., \& Kuchay, N. A. (2011). Anthropogenic Impact on Forest Cover in the Western Himalayas-A Case Study of Lidder Catchment in Kashmir Valley. Transactions of the Institute of Indian Geographers, 33, 55-65.

McCool, S. F. (1995). Linking Tourism the Environmental, and Concepts of Sustainability: Setting the Stage. In S. F. McCool, \& A. E. Watson (Eds.), comps. Linking Tourism, the Environment at, and Sustainability. Gen. Tech. Rep. INNNT-GTR-323, Ogden, UT: USDA, Forest Service, Intermountain Research.

Mirsepasi, N. (2004). Strategy of Human Resources and Labor Relations. Tehran: Mir Publications.

Mohseni Tabrizi, A. R., \& Aqamohseni, M. (2010). The Role of Social Capital in Urban Development; Case Study: Mahallat City. Urban Management Journal, No. 26, 147-162.

Nunkoo, R., \& Ramkissoon, H. (2011). Residents' Satisfaction with Community Attributes and Support for Tourism. Journal of Hospitality and Tourism Research, 35, 171-190.

http://dx.doi.org/10.1177/1096348010384600

Ostad Hoseyn, R., \& Kohnabi, S. (2003). The Role of Universities in Regional Development. Economic Journal, No. 27, 28.

Pusiran, A. K., \& Xiao, H. (2013). Challenges and Community Development: A Case Study of Homestay in Malaysia. Asian Social Science, 9, 1-17. http://dx.doi.org/10.5539/ass.v9n5p1

Putnam, R. D. (1995). Bowling Alone: America Declining Social Capital. Journal of Democracy, 6, 65-78. http://dx.doi.org/10.1353/jod.1995.0002

Rashid, I., \& Romshoo, S. A. (2012). Impact of Anthropogenic Activities on Water Quality of Lidder River in Kashmir Himalayas. Environmental Monitoring and Assessment, 185, 47054719. http://dx.doi.org/10.1007/s10661-012-2898-0

Rastgar Khaled, A., Aran Dashti Arani, S., \& Sadeqi Arani, Z. (2013). Neighborhood Social Capital and Main Outcomes Associated with It (Case Study: Aran o Bidgol City, Aran Region). Studies of Social-Cultural Development, 1, 177-215.

Salari Sardari, F., Biranvandzade, M., \& Alizade, S. D. (2014). The Role of Social Capital in Local Sustainable Development. City Identity, No. 19, 77-88.

Shahabian, P. (2010). The Role of Tourism Development in Sustainable Urban Development. Ph.D. Thesis, Tehran: Islamic Azad University, Science and Research Branch.

Spitzer, H. (1997). Fünf Ebenen der Nachhaltigkeit. In M. Birzer, P. H. Feindt, E. A. Spindler (Eds.), (Pub.) Nachhaltige Stadtentwicklung: Konzepte und Projekte. Bonn: Economica Verlag. 
Szpilko, D. (2015). The Future of Tourism Development in the Podlaskie Voivodeship. Procedia-Social and Behavioral Sciences, 213, 977-984. http://dx.doi.org/10.1016/j.sbspro.2015.11.514

Tabrizi, M. A. (1990). Barrier to Participation, Alienation, National Development, the Relationship between Alienation, Social Participation, Political, Cultural. Center for Basic Research, Ministry of Culture and Islamic. Research Journal, No. 1.

Tavakoli, M., \& Tajbakhsh, K. (2008). Analysis of Social Capital Amount in Border Urban and Rural Areas of Sistan. Journal of Village and Development, No. 2, 143-162.

Timothy, D. J., \& Wall, G. (1995). Tourist Accommodation in an Asian Historic City. The Journal of Tourism Studies, 6, 23-24.

University of Dortmund (2001). Sustainable Regional Development for Tourism in County Donegal. Republic of Ireland, Faculty of Spatial Planning.

Woolcock, M., \& Narayan, D. (2000). Social Capital: Implications for Development Theory, Research, and Policy. The World Bank Research Observer, 15, 225-249.

http://dx.doi.org/10.1093/wbro/15.2.225

Zabortseva, T. I., \& Yevstropieva, O. V. (2009). Current Socio-Ecological Problems of Recreational Development of Pribaikalsky National Park. Geography and Natural Resources, 30, 359 366. http://dx.doi.org/10.1016/j.gnr.2009.11.010

Zahedi, Sh. (2006). Principles of Sustainable Tourism and Ecotourism. Tehran: Allameh Tabatabai University Publications.

Zhang, Q., \& Hung, H. G. (2006). China's Social Capital and Financial Performance of Private Enterprises. Journal of Small Business and Enterprise Development, 13, 198-207.

\section{Submit or recommend next manuscript to SCIRP and we will provide best service} for you:

Accepting pre-submission inquiries through Email, Facebook, LinkedIn, Twitter, etc.

A wide selection of journals (inclusive of 9 subjects, more than 200 journals)

Providing 24-hour high-quality service

User-friendly online submission system

Fair and swift peer-review system

Efficient typesetting and proofreading procedure

Display of the result of downloads and visits, as well as the number of cited articles

Maximum dissemination of your research work

Submit your manuscript at: http://papersubmission.scirp.org/

Or contact cus@scirp.org 